\title{
Ideologie politică și ideologie literară în „Scânteia tineretului" - anul 1969
}

\author{
Prof. univ. dr. Nicoleta IFRIM \\ Centrul interdisciplinar de studii culturale central și sud-est europene, \\ Universitatea "Dunărea de Jos" din Galați
}

\begin{abstract}
Our study presents in detail the main articles published in 'Scânteia tineretului' (1969) in order to portray the totalitarian doctrine influencing literature and critical discourse of 1969 .
\end{abstract}

Keywords : ideology, literature, totalitarian doctrine, "Scânteia tineretului".

„Scânteia tineretului" publică, pe parcursul anului 1969, articole prin care poziția ideologizantă față de literatură este explicită, discursul acestora erijându-se într-un rețetar legitimant care propune grile specifice, încărcate ideologic, de validare a textelor literare. Propunem, în continuare, un tablou descriptive, ordonat cronologic, al acestor publicaţii.

În 16 ianuarie, Demostene Botez glosează despre Valorile culturale - tezaut al întregului popor, notând faptul că „Înflorirea culturii noastre este reflectarea firească, consecința directă a eliberării patriei noastre și, implicit, a eliberării omului, dezvoltării conștiinței sale socialiste. (...) Cultura maselor constituie o condiție primordială a construcției socialiste. Socialismul cere și generează cultură." (Nr. 6114, joi, 16 ianuarie)

Pompiliu Marcea publică, în "Scânteia tineretului” din 21 ianuarie, articolul Artistul - produsul vremii sale, susținând că „relația dintre scriitor și societatea în care trăiește nu este numai una de simplă dependență sau de acceptare mecanică de către scriitor a dezideratelor sau gustului epocii. În același timp, nimeni nu poate obliga societatea să valorifice un scriitor în care nu se recunoaște, pe planul gândirii sau al sensibilității. De aceea, raportul cel mai exact, bazat pe experiența artistică anterioară, este unul de influență reciprocă, inevitabilă și necesară în același timp. Un asemenea raport are cele mai mari șanse să fie validat din punct de vedere teoretic pentru simplul motiv că omul și deci și artistul este produsul vremii sale și în același timp pentru că epoca poartă pecetea marilor personalități ce o străbat." (Nr. 6118, marți, 21 ianuarie)

În 23 ianuarie se continuă ancheta literară cu tema Experiența de viață - o noțiune perimată?, inițiată în numărul 6116 / 18 ianuarie, la care răspund acum Aurel Dragoș Munteanu și Nicolae Dragoș. Scriind despre Istorie și creație, Aurel 
Dragoș Munteanu consideră că, fiind „legată de artist, în primele faze, independentă de el pe urmă, opera de artă semnifică pentru istorie. (...) Ea constituie o realitate proprie, $\mathrm{cu}$ o densitate uneori mai mare. Regimul ei nu aparține decât istoriei, ca fapt subiectiv și creație umană." Glosând despre Atitudinea scriitorului de a se situa în epocă, Nicolae Dragoș noteză că „prin experiența de viață înțeleg (...) aptitudinea creatorului de a se situa în epocă, de a-și contrui prin operă o biografie socială, spirituală, de a aduna în focarul exigent al lucidităţii creatoare evenimentele timpului său cărora le este nu numai contemporan, dar de ale căror implicații este legată însăși afirmarea personalității sale pe cele mai diverse planuri." (Nr. 6120, joi, 23 ianuarie)

În 25 ianuarie se continuă ancheta literară cu tema Experiența de viață - o noțiune perimată?, cu intervenții ale tinerilor scriitori și critici. Alexandru Andrițoiu scrie câteva Glose la corelația poezie - massă: „În privința ținutei ideologice și civice a poeților noștri contemporani: cred că tot ce are mai bun poezia noastră de azi, în toate stilurile și de toate generațiile stă sub steag și este legat de destinul patriei și al umanității. Văd însă un gol îngrijorător în ținuta etică a unor poeți neînzestrați, care intră în poezie pe scara din dos, sub ochii deo papală clemență a criticii literare.” Pentru Gheorghe Suciu, artistul este „un martor care judecă”, iar „experiența de viață a artistului se măsoară în opere.” Eugen Simion vorbește despre $O$ „aventură" în lumea cunoașterii, care trebuie să ducă la valori, căci „experiența în literatură e un proces în doi timpi: actul trăit sau imaginat $\mathrm{cu}$ sinceritate, bazat, cum spuneam, pe date existențiale fundamentale și, al doilea moment, meditația asupra lui, ridicarea, adică, a experienței individuale la simbol și la viziune. Sub această din urmă ipostază, experiența devine, să întrebuințăm o formulă ignobilă, fapt de artă." (Nr. 6122, sâmbătă, 25 ianuarie)

În „Scânteia tineretului” din 29 ianuarie, Barbu Cioculescu remarcă Polivalența inepuizabilă a artei, iar „condiția scriitorului este demonstrată de încrederea care i se acordă, de recunoașterea rolului său spiritual, de încurajările care i se aduc, spre a fi un factor social activ și responsabil în spiritul principiilor marxist-leninismului. Societatea pretinde cu insistență scriitorului să-i determine specificul și trăirea, mutațiile, ăn note acute și lucide, în trăsături vii și sigure." (Nr. 6125, miercuri, 29 ianuarie)

În numărul din 1 februarie, Sânziana Pop scrie despre Experiență și valoare, considerînd că „Experiența de viață a scriitorului este experiența de viață a unui om normal și numai experiența spirituală, capacitatea de concentrare asupra mediului, capacitatea de observare și înțelegere, capacitatea 
de reproducere estetică este aceea care-i hotărăște valoarea și soarta." (Nr. 6128, sâmbătă, 1 februarie)

C.Stănescu publică, în „Scânteia tineretului” din 11 februarie, un amplu articol cu miză ideologizantă, Reconsiderarea literară trebuie să aibă în vedere întregul adevăr istoric, în care criticul își afirmă tranșant poziția: „În lumina concepției materialist-istorice recosntituirea imaginii trecutului este echivalentă cu o reformulare creatoare, în primul rând, al tuturor valorilor mari, progresiste, acelea în care spiritul poporului și-a găsit cele mai mari realizări. (...) În acest climat se situează opiniile formulate în Contemporanul, Scânteia, România literară pe marginea antologiei Poezia română modernă - de la G.Bacovia la Emil Botta, alcătuită de Nicolae Manolescu sub egida Editurii pentru Literatură. Asupra obiecțiilor multiple ce pot decurge din subiectivitatea autorului, din natura gustului său (firești între anumite limite) nu ne propunem să discută, ele fiind expuse cu claritate de profesorul universitar și istoricul literar George Ivașcu în Contemporanul, de profesorul universitar Șerban Cioculescu, membru corespondent al Academiei Republicii Socialiste România, în România literară și profesorul universitar al.Dima, membru corespondent al Academiei Republicii Socialiste România, în Scânteia. (...) Prezența în antologia citată a unor scriitori grav implicați în curente ideologice reacționare, în mișcarea legionară (Nichifor Crainic, Radu Gyr, Aron Cotruș ș.a.) pretindea deci cu necesitate o informare cuprinzătoare precum și (...) o evaluare critică fermă a întregii lor activități." (Nr. 6137, marți, 11 februarie)

În 22 februarie, Florin Mugur publică un interviu cu Mihai Ungheanu despre Experiența scriitorului adevărat, în care criticul declară: „Un scriitor trebuie să știe din ce se trage și ce reprezintă și ce reprezintă el astăzi în angrenajul social. Să aibă conștiința persoanei sale, a valorii ei sociale, a familiei sale, a neamului său, a destinului acestei spițe, ca și a situării ei în marele organism social din care face parte. (...) Scriitorul nu se poate închipui în afara atitudinii voluntare." (Nr. 6147, sâmbătă, 22 februarie)

Numărul din 20 martie publică un interviu cu Nicolae Breban despre Romanul social, în care scriitorul afirmă: „Chestiunea regăsirii și continuării tradiției romanului social românesc este de un interes acut, nu numai scriitoricesc, ci și patriotic. În ce mă privește, așa cum arată și a treia carte a mea, Animale bolnave, cred într-o resurecție a romanului clasic, într-o reinstalare în prerogativele sale majore a personajului, a intrigii, a construcției de tip tradițional. (...) Romanul este mai puternic decât bolile sale momentane (noul val este una dintre boli, dogmatismul e alta). Voi milita cu forță pentru a reactualiza forma romanului clasic, cu modalități însă mai greu de ghicit, într-o aparență 
nouă, răspunzând rapid și profund sensibilității omului de astăzi." (Nr. 6170, joi, 20 martie)

În 2 aprilie, Florin Mugur publică un interviu cu Nichita Stănescu despre Secretul poeziei, în care poetul își legitimează opțiunea estetică: „Cred că poezia nu ține în nici un caz de cuvânt, cuvântul fiind, cum am mai spus în diferite articole, un simplu vehicul. Evident, cel mai suav vehicul, dar nu fundamental necesar. Poezia trăiește în însăși existența noastră. (...) Poezia se adună, se încheagă, se cristalizează din niște foarte curioase și unice revelații. (...) Nu am să încerc să dau o definiție a poeziei sociale, deși poate că poezia socială e mai ușor de definit decât poezia în genere. O văd ca o aplicație a eului individual, în social. Ea se plasează la zona de intersecție între eu și noi. Poezia socială este o dimensiune de neînlocuit, a oricărui poet viu. În intenția mea, Roşu vertical, pe lângă sensul de adeziune la contemporaneitatea țării mele, poate să aibă și un sens polemic. Poate n-am reușit pe deplin. În orice caz, eu consider acest volum primul dintr-un șir de cărți pe care intenționez să le scriu, dedicate țării și (mai precis) destinului ei politic. Sensul polemic al cărții era strict estetic." (Nr. 6181, miercuri, 2 aprilie)

Nicolae Baltag semnalează, în „Scânteia tineretului” din 11 aprilie, debutul poetic al lui Marin Mincu, cu volumul Cumpănă, în care „nota diferențiatoare (...) rezidă într-o elaborare mai rece, mai livrescă. Poetul se implică mai puțin, își angajează doar postura stilizat-lirică, care nu-l reprezintă în întregime, în aceste dramatice sondaje în abisurile conștiinței. Impresia de manierism nu se șterge cu totul, dar ea este energic combătută de suficiente dovezi de lirism autentic." (Nr. 6189, vineri, 11 aprilie)

Sunt publicate, în 12 aprilie, în secțiunea dezbatere asupra Romanului social, articolele lui Constantin Stoiciu, Șansa exprimării totale („Literatura ultimelor noastre două decenii nu și-a declinat sub nici o formă misiunea, condiția sa existențială: finalitatea umană, implicit socială.(...) Romanul cu adevărat social nu poate fi decât un roman clasic.") și Dragoș Vrânceanu, Unghiul perspectivei etice (,Romanul social poate să nu fie chiar roman social, de tip sociologic, ci un roman liber în care personajele, urmărind pantomima lor, să devină niște adevărați medici fără voie ai raporturilor dintre individ și societate, adică să pună diagnoze sociale necontenite în legătură cu rănile lor și cu tratarea sau autotratarea lor, reintroducând fenomenul societății în psihologia individuală măcar pe acestă cale, dacă romancierul nu se poate sustrage fscinației introversiunii.") (Nr. 6190, sâmbătă, 12 aprilie)

În „Scânteia tineretului" din 21 aprilie, Pompiliu Marcea publică un articol dedicat lui Camil Petrescu, cu ocazia împlinirii a 75 de ani de la nașterea 
scriitorului, în care sunt re-evaluați eroii camilpetrescieni din punct de vedere al „raportului integrității morale.” Astfel, Gelu Rușcanu, Andrei Pietraru, Ladima, Ștefan Gheorghidiu ajung într-o „ostilitate ireconciliabilă cu mediul din jur. (...) A fost, însă, zadarnică jertfă? Nu, pe dată ce, chiar pentru o clipă, oamenii aceștia au arătat semenilor un alt chip decât cel obișnuit, mai pur și mai frumos, trezind măcar o undă de nostalgie pentru ceea ce trebuie să fie omul adevărat. Acesta este sensul superior educativ al întregii opere a lui Camil Petrescu scrisă înainte de Eliberare. Înțelegem acum mai bine adeziunea, nu lipsită de inerente oscilații, dar cu atât mai profundă a scriitorului pentru ideile socialismului, pentru filozofia marxistă." (Nr. 6197, luni, 21 aprilie)

În 24 aprilie, C.Stănescu recenzează cartea de debut al lui Vasile Văduva, Roagă-te pentru mine, în care nu apare „nimic exagerat, lipsește poza, afectarea, stângăciile atâtor scriitori aflați nu doar la prima carte", precum și „romanul-anchetă” al lui D.R.Popescu, F, a cărui „performanță” constă în faptul „de a găsi fiecărui act, fiecărui gest al personajelor, echivalentul simbolic. (...) Dacă acest fel de a gândi literatura - ca o posibilitate de a medita pe marginea vieții și pornind de la ea - își are rațiunile sale de a încerca să existe, șansa acestei literaturi nu stă în modul însuși de a o gândi ci în ceea ce o poate susține: creația de viață din a cărei iluzie însușită total se nasc și există personajele, eroii care rămân, dincolo de orice demonstrație." (Nr. 6200, joi, 24 aprilie)

Mihai Ungheanu publică, în „Scânteia tineretului" din 14 mai, Dialogul cronicarului literar, în care identifică unele abateri de la „deontologia critică”: „Una din bolile cronicii este spectacolul pe care inteligența criticului vrea să-1 ofere spectatorilor săi. Cărțile devin pretexte alteori există o fascinație a judecății drastice. Pot intra pe eșafod și produse ce merită un tratament atent. Altă boală e poza distantă: a nu scrie despre cărțile proaste. E adevărat că acestea sunt foarte multe și că a scrie despre ele e o pierdere de vreme. Dar există între aceste false glorii care trebuie înlăturate și produse care sintetizează șablonul nociv, producția de serie. Printr-un singur exemplar poate fi executată o serie întreagă de afini." (Nr. 6216, miercuri, 14 mai)

Florin Mugur publică, în 11 iunie, un interviu cu Eugen Simion despre Arta criticii literare, care legitimează statutul criticului și al exercițiului său interpretativ: „Cine vrea însă (...) să fie critic și nu agent de publicitate al unui grup de prieteni cu preocupări literare, trebuie să aibă perspectiva întregii culturi, să vrea și să lupte pentru impunerea valorilor adevărate, indiferent din ce direcție estetică vin. Acolo unde există o unică iubire, în literatură, fanatismul critic e de neînlăturat. (...) Critica înseamnă justificare estetică." (Nr. 6240, 
miercuri, 11 iunie) Aurel Baranga publică, în „Scânteia tineretului" din 30 iunie, articolul Dimensiunea umanistă a poeziei: „Poezia umanismului socialist s-a reîmpăcat cu rostul ei inițial: poezia ceremonial, în întregime pusă în serviciul OMULUI pe care îl definește definindu-se. Și în acest semnificat vârtej de contradicții magistrale, OMUL-CÂNTAT devine OMUL-CÂNTEC, poetul transformând incantația în decret lucid spre satisfacția mulțimilor aderente la poezie ca la un rost al lor firesc." (Nr. 6256, luni, 30 iunie) Ov.S.Crohmălniceanu prezintă, în „Scânteia tineretului" din 2 iulie, romanul Un om între oameni, al lui Camil Petrescu, o „primă încercare reușită la noi de a propune literaturii de reconstituire istorică o formulă nesadoveniană. (...) Dacă vorbim azi de o atitudine patriotică, nu numai sentimentală, bizuită pe înțelegerea mecanismelor social-istorice și pe ideile marilor răspunderi colective, în romanul lui Camil Petrescu o găsim exprimată cu o ardență ridicată la incandescența intelectualului." (Nr. 6258, miercuri, 2 iulie)

"Scânteia tineretului" din 5 iulie propune ancheta Tineretului - o literatură izvorâtă din realitatea epocii noastre, la care răspund Demostene Botez ( $A$ vorbi aceeași limbă cu cei cărora te adresezi - eroul socialist „e lipsit de panașul ostentativ și spectacular ce caracteriza eroul altor epoci. Calităţile pozitive ale omului sunt în genere lipsite de spectaculozitate și bravadă, ele presupunând în fondul lor și modestia, ca și conștiința superioară că asemenea calități trebuie să fie firești oricărui om în societatea socialistă."), Ion Băieșu (Un fond problematic comun „datoria scriitorului este, cum se spune în Tezele Congresului al X-lea, de a scrie despre oamenii - implicit tinerii - acestei epoci, despre cei care muncesc cu prețul obținerii profilului nou al țării și poporului nostru."), Fănuș Neagu (Modificarea conștiinței - „literatura tulbură conștiințe, deci le modifică, dar asta pe o perioadă de timp care se măsoară în decenii."), Gheorghe Suciu (Există eroi pozitivi! - „A împărtăși cu un erou și a aspira sprev dânsul, iată o modalitate de a educa a literaturii. Totul e ca literatura să nască și să propună asemenea eroi pozitivi, cât mai integri, oameni în primul rând spre care sufletul mai cu seamă tânăr aspiră."), Maria Banuș (Educație prin selecție - „Nu cred într-o literatură scrisă special pentru uzul tineretului.") (Nr. 6261, sâmbătă, 5 iulie)

Florin Mugur publică, în numărul din 13 iulie, un interviu cu Cezar Baltag despre Condiția poeziei, în care poetul declară că „Mă fascina la Nichita Stănescu spontaneitatea sa strălucitoare, inteligența sa înnăscută. (...) Prietenia cu Nichita Stănescu, cu Matei Călinescu, cu Grigore Hagiu, cu Nicolae Velea, cu Nicolae Breban, a avut un rol hotărâtor pentru formarea mea. (...) Cuvintele, metaforele traduc așadar în termenii concretului sensibil relația de determinare sau de indeterminare, cum vrei, a existenței. (...) Ceea ce mi se pare esențial în 
cazul lui Labiș este faptul că lirica lui a avut o fierbinte acoperire în existență, în destinul său nepereche, puternic și tragic. (...) Poeții sunt niște monade, fiecare cu sensibilitatea sa ireductibilă. Toate aceste monade se acordează însă cu o mare monadă care este societatea. (...) Un sentiment cum este acela al patriei este un sentiment profund poetic și profund inefabil, capabil să fie transformat, în retorta spirituală a marilor poeți, în poezie manifestă de cea mai bună calitate." (Nr. 6268, duminică, 13 iulie)

În 22 iulie, S.Damian prezintă Moromeții, considerând că „Dacă la Rebreanu obsesiile materiale, pofta de îmbogățire duceau la sacrificarea umanului (Ion), Marin Preda e preocupat de procesul invers, al recuperării frumosului moral prin abstragerea din concretul devorator. (...) Această demonstrare a raportării la social și etic, a determinismului istoric explică neobișnuita forță a investigației psihologice, remarcată în Moromeții." (Nr. 6276, marți, 22 iulie)

Costin Bratu publică, în 30 iulie, un interviu cu Șerban Cioculescu, Scriitorul găsește în societatea noastră surse de reflecție și de inspirație, în care acesta își conturează poziția critică față de ipostaza scriitorului contemporan: „Prefer strictelor delimitări observarea evoluției literare însăși”, , "Consecințele ultimului război mondial lasă deschise atâtea soluții”, ,"Kafka și Joyce domină o parte a prozei noastre actuale, dar...atenție! Epigonismul înseamnă impas", "Cunoașterea prin artă presupune investigații umane profunde", „Marile evenimente socialiste contemporane nu pot fi decât pe măsura marilor artiști", "Criticul trebuie să aibă încredere în recepția sa estetică”, „Cred în literatura tinerilor." (Nr. 6283, miercuri, 30 iulie)

În 19 august, Laurențiu Ulici prezintă romanul Străinul de Titus Popovici, „un roman de contact, închizând în el atât afirmarea individualismului burghez și a valorilor materiale. (...) Justificarea acestei duble problematici stă în contextul istoric al desfășurării evenimentelor din roman: România în anii războiului, ai mișcării antifasciste și ai eliberării. Cea mai exactă încadrare a Străinului mi se pare a fi în categoria bildungsromanului." (Nr. 6301, marți, 19 august). Nicolae Baltag semnalează debutul lui Norman Manea cu volumul Noaptea pe latura lungă, constatând că „proza lui Norman Manea este mărturia unei anumite vârste - tinerețea și a unui timp anume - epoca postbelică. Recunoști ușor, nu doar situații și peisaje, ci un ritm, un timbru și o psihologie pregnant contemporane. Prin aceasta, și în ciuda unor estompări de moment ale cadrului, scriitorul este solidar - în arta sa - cu prezentul. Când va deprinde mai ferm legile perspectivei, racordarea la viitor ar putea deveni ea însăși o realitate." (Nr. 6310, vineri, 29 august). În 11 octombrie, Ilie Constantin 
semnează articolul Fereastra tânărului prozator, în care constată că „Proza tinerilor debutanți, mai mult decât debuturile în poezie unde inspirația fericită poate duce tot greul, oferă la lectură satisfacții incomplete. (...) În faza începuturilor, de exemplu, a scrie bine despre orice, a-ți alege subiectele din medii foarte diferite, tratându-le în maniere felurite nu e, în principiu, o greșeală și nu se poate spune că face bine numai acel care își oprește privirea doar asupra unui sector existențial, cunoscut bine, insistând exclusiv spre configurarea lui. E adevărat că, în ce ne privește, cătăm cu mai multă speranță spre aceștia din urmă și că ne produce oarecare îngrijorare talentul rece, aplicabil cu detașare la orice obiect." (Nr. 6347, sâmbătă, 11 octombrie)

Această prezentare strict descriptivă și cronologică a articolelor publicate în „Scânteia tineretului” - anul 1969 va fi inclusă, în formă revizuită și adăugită, în volumul care urmează a fi publicat din Cronologia vieții literare românești. Perioada postbelică, anul 1969 (coordonare generală şi prefaţă - Acad. Eugen Simion; coordonator redacțional al ediției - Lucian Chișu) la Editura Muzeul Naţional al Literaturii Române.

\section{Bibliografie:}

Antofi, Simona, General Dictionary of Romanian Literature - Obverse and Reverse Critical Reception, în Oana Cenac (coord., edit.), International Conference of Common Vocabulary/Specialized Vocabulary: Manifestations of Creativity of Human Language, 6-7 iunie 2014, publicate în volumul MANIFESTARI ALE CREATIVITATII LIMBAJULUI UMAN, 2014, p. 13-19, ISBN:978-606-17-0623-5, WOS:000378446400001, https://apps.webofknowledge.com/full record.do?product $=W O$ SEsearch mode $=$ GeneralSearchEqid $=2 \mathcal{E} S I D=N 1$ izysiav2 $\mathrm{ciPKZmp8PEpage=1 \mathcal {E } \text { doc } = 3}$

Cenac Oana, Discurs ideologic în "Ateneu" 1965, Actele conferinței internaţionale Lexic comun / Lexic specializat. Democratizarea cunoașterii" sau migrația lexicului specializat spre lexicul comun, ediția a X-a, Universitatea "Dunărea de Jos” din Galați, Facultatea de Litere, Centrul de Cercetare Comunicare interculturală și literatură, 19 - 20 mai 2017, publicată în Analele Universității „Dunărea de Jos” din Galați, Fascicula XXIV Lexic comun / lexic specializat, revistă indexată in bazele de date internaționale EBSCO: https://www.ebscohost.com/titleLists/cmscoverage.pdf, MLA (Modern Language Association, New York, www.mla.org) $M L A$ International Bibliography $\mathcal{E}$ Directory of Periodicals, CEEOL și Fabula. La recherche en littérature (www.fabula.org), anul X, nr. 2(18) /2017, Editura Casa Cărții de Ştiință, Cluj-Napoca, 2017, ISSN 1844-9476, p. 31-48. 
Cenac Oana, General aspects of current political terminology, în Lexic politic - discurs politic, 2014, p.124-130, ISBN:978-606-17-0633-4, WOS: 000378358200007.

Ifrim, Nicoleta, History and Identity in Post-Totalitarian Memoir Writing in Romanian, CLCWeb: Comparative Literature and Culture (ISSN 1481-4374) http://docs.lib.purdue.edu/clcweb/, nr. 16.1 / March 2014, Purdue University Press, revistă indexată ISI Art and Humanities Citation Index http://docs.lib.purdue.edu/clcweb/vol16/iss1/11/, Accession Number WOS:000333326200011.

Scânteia tineretului, 1969. 